\title{
Peranan Perempuan Kelompok Sentosa Sasak Tenun di Desa Wisata Pringgasela Kabupaten Lombok Timur
}

Ziyadatur Rohmi 1 a, 1, I Gst. Agung Oka Mahagangga 2 a, 2

${ }_{1}^{1}$ ziyadaturrohmi97@gmail.com, ${ }^{2}$ okamahagangga@unud.ac.id

a Program Studi S1 Destinasi Pariwisata, Fakultas Pariwisata, Universitas Udayana, Jl. Dr. R. Goris, Denpasar, Bali 80232 Indonesia

\begin{abstract}
The gedogan woven fabric business is one of the businesses that can contribute to improving the community's economy as well as being supporting tourism product activities in East Lombok Regency. Women have the power to be more empowered in improving family welfare. This study aims to determine the role of women in the development of the gedogan weaving business in the Sentosa Sasak Tenun Group at Pringgasela Tourism Village, East Lombok Regency.

In this study using qualitative and quantitative data types, while the data sources used are primary and secondary. Data collection techniques in this study using observation techniques, in-depth interviews and documentation. The informant determination technique used is purposive sampling technique. The data analysis technique used is qualitative descriptive data analysis.

The results showed that the role of women in the Sentosa Sasak Tenun Group on productive roles was as weaving craftsmen, farmers, farm laborers, farm laborers, breeders, and home traders. The reproductive role of women weavers is managing the household. Meanwhile, the social role in the community, namely, as a member of the Muslimat related to religious events, cooperation activities between communities or traditional events which in Sasak is called gawe belek, and the health group namely Work Health Efforts. Of the three role models, the main role of women in the Sentosa Sasak Tenun Group is their reproductive role, because as a wife and mother, the nature of a woman is managing household affairs.
\end{abstract}

Keywords: women's role, small business, crafts, weaving, tourism village

\section{PENDAHULUAN}

Pariwisata tidak dapat diingkari memiliki ragam atau dimensi. Dimensi pariwisata tidak hanya dimensi ekonomi, melainkan dimensi lingkungan, dimensi politik, dimensi sosial budaya, dimensi sejarah dan dimensi lainnya. Sebagai ilmu pengetahuan pariwisata dapat dilihat dari berbagai perspektif sesuai dengan fakta empiris di lapangan maupun hasil refleksi dari para pakar. Hal ini yang membuat ilmu pariwisata sangat prospektif kedepan dengan penekanan kepada aspek akademis maupun aspek praktis (Anom dan Mahagangga, 2020).

Secara historis, Bangsa Indonesia berangkat dari keragaman atas kekayaan warisan budaya yang dimiliki. Salah satu warisan budaya Indonesia, yakni keragaman kain tenun tradisional. Masing-masing daerah tentunya memiliki ragam motif dan makna tersendiri mengenai kerajinan kain tenun tradisional. Salah satu contohnya, yakni kerajinan tenun tradisional yang ada di Pulau Lombok.

Pulau Lombok merupakan pulau yang menjadi salah satu ikon pariwisata Indonesia yang kaya akan potensi keindahan alam dan budayanya. Kerajinan tenun tradisional di Pulau Lombok telah ada sejak abad ke-14 Masehi. Salah satu daerah yang masih bertahan mengembangkan kerajinan tenun tradisional tersebut sampai saat ini adalah Desa Wisata Pringgasela, Kabupaten Lombok Timur. Kain tenun tersebut lebih dikenal dengan sebutan kain tenun gedogan, karena pada proses pembuatan, teknik, peralatan dan perlengkapannya masih menggunakan alat yang sangat sederhana.

Partisipasi aktif kaum perempuan dalam ekonomi rumah tangga melalui usaha kerajinan tenun gedogan, secara perlahan dapat membawa kaum perempuan menjadi lebih mandiri Terutama dalam pengambilan keputusan di berbagai bidang kehidupan. Melihat hal tersebut, maka Kelompok Sentosa Sasak Tenun didirikan dengan tujuan untuk melestarikan kerajinan tenun gedogan, sekaligus sebagai wadah para pengrajin untuk menerapkan dan mengembangkan pengetahuan serta keterampilan mereka dalam kegiatan menenun.

Menurut Hartanto dan Firdausy (2010), menjelaskan bahwa di Indonesia kepedulian terhadap perempuan adalah dengan adanya instruksi Presiden Republik Indonesia Nomor 9 tahun 2000 tentang Pengarusutamaan Gender dalam Pembangunan Nasional. Menurut Ahdiah (2013), berpendapat bahwa penguatan peran perempuan dalam dunia dapat dilihat pada tuntutan internasional yang terdapat dalam Millenium Development Goals yang harus dipenuhi pada tahun 2015, dan Indonesia menjadi salah satu negara yang ikut mendeklarasikan MDGs sebagai bagian dari pencapaian kemajuan bangsa. Vivekananda dalam (Manembu, 2017), mengungkapkan suatu negara yang tidak menghormati kaum perempuannya tidak akan pernah menjadi negara yang besar, baik di saat ini, maupun di masa depan. 
Pelestarian dan pengembangan kerajinan tenun gedogan sebagai aset budaya daerah memang tidak bisa dipisahkan dari peran aktif kaum perempuan desa sebagai pengrajin tenun. Secara tidak langsung, hal tersebut akan dapat meningkatkan keeksistensian dan kesejahteraan ekonomi perempuan. Sekaligus menjadi salah satu upaya untuk mengembangkan daya tarik wisata budaya di Desa Wisata Pringgasela. Peran aktif kaum perempuan sebagai pengrajin tenun, tentunya perlu mendapatkan dukungan yang maksimal dari semua komponen aktor. Hal tersebut merupakan salah satu upaya agar giat para pengrajin tenun, khususnya pengrajin perempuan, semakin terpacu untuk tetap konsisten dalam menjalankan peranannya. Sebagai pengrajin tenun, tentu kaum perempuan di Desa Wisata Pringgasela memiliki peranan lain. Oleh karena itu, perlu dilakukan penelitian mengenai peranan perempuan tersebut dengan mengambil studi kasus yaitu Kelompok Sentosa Sasak Tenun, untuk mengetahui peranan apa saja yang dimiliki oleh kaum perempuan di Desa Wisata Pringgasela selain sebagai pengrajin tenun.

Berdasarkan uraian latar belakang tersebut, maka dapat dirumuskan permasalahan pokok dalam penelitian ini, yaitu bagaimana peranan perempuan Kelompok Sentosa Sasak Tenun di Desa Wisata Pringgasela, Kabupaten Lombok Timur?. Adapun tujuan dilakukannya penelitian ini adalah untuk mengetahui apa saja peranan perempuan Kelompok Sentosa Sasak Tenun di Desa Wisata Pringgasela, Kabupaten Lombok Timur. Dan hasil dari penelitian ini diharapkan dapat bermanfaat secara praktis dan akademis.

\section{TINJAUAN PUSTAKA}

\section{A. Telaah Penelitian Sebelumnya}

Mencegah penelitian ganda, maka telaah hasil penelitian sebelumnya sangat penting untuk dikaji. Adapun penelitian pertama yang dijadikan referensi dalam penelitian ini adalah jurnal yang diteliti oleh Pratiwi dan Nugroho (2013). Penelitian kedua adalah jurnal yang diteliti oleh Manembu (2017). Penelitian ketiga adalah jurnal yang diteliti oleh Kartia (2017).

Berdasarkan kajian dari ketiga telaah penelitian sebelumnya tersebut, dapat disimpulkan bahwa penelitian terkait analisis terhadap peranan perempuan pengrajin tenun di Desa Wisata Pringgasela dengan mengambil studi kasus pada Kelompok Sentosa Sasak Tenun sangat penting untuk dilakukan. Melihat fakta referensi publik bahwa topik penelitian ini belum pernah dilakukan dan dipublish dalam penelitian sebelumnya, baik terkait fokus, lokus dan metode penelitian. Hal itulah yang menjadi justifikasi kebaruan dalam penelitian ini. Sehingga hasil penelitian dapat menjadi rantai referensi untuk penelitian selanjutnya.

\section{B. Landasan Konsep}

Konsep yang digunakan sebagai referensi untuk menganalisis rumusan masalah dalam penelitian ini, meliputi konsep peranan dengan menggunakan pendekatan Model Tiga Peranan (Moser dalam Dewi dan Mahagangga, 2016), konsep perempuan (Ritzer dan Goodman dalam Ahdiah, 2013), konsep gender (Puspitawati dalam Dewi dan Mahagangga, 2016), konsep kerajinan (Howkins, 2001), konsep tenun (Intani, 2010), dan konsep Usaha Mikro Kecil dan Menengah (Suci, 2017).

\section{METODE PENELITIAN}

Penelitian ini dilakukan di Desa Wisata Pringgasela, Kecamatan Pringgasela, Kabupaten Lombok Timur, Provinsi Nusa Tenggara Barat. Penelitian ini dilakukan mulai tanggal 24 April 2019 sampai dengan 8 Mei 2019. Ruang lingkup penelitian ini, yaitu peranan perempuan Kelompok Sentosa Sasak Tenun berdasarkan Model Tiga Peranan, yang terdiri dari peran produktif, peran reproduktif dan peran sosial. Dalam penelitian ini menggunakan dua jenis data, yaitu data kualitatif dan data kuantitatif Penelitian ini menggunakan dua sumber data, yaitu data primer dan data sekunder (Bungin, 2007).

Data dalam penelitian ini didapat melalui teknik observasi (Suryawan dan Mahagangga, 2017), wawancara mendalam (Bungin, 2007dan dokumentasi (Moleong, 2012). Adapun teknik penentuan informan yang digunakan dalam penelitian ini adalah purposive sampling (Bungin, 2007). Sedangkan, teknik analisis data yang digunakan dalam penelitian ini, yaitu deskriptif kualitatif (Arikunto, 2006).

\section{HASIL DAN PEMBAHASAN}

\section{A. Gambaran Umum Kelompok Sentosa Sasak Tenun}

Galeri Sentosa Sasak Tenun berlokasi di Jalan Rinjani, RW Sentosa, Desa Wisata Pringgasela, Kecamatan Pringgasela, Kabupaten Lombok Timur. Kelompok Sentosa Sasak Tenun berdiri pada tahun 2000. Latar belakang berdirinya kelompok tenun ini, berawal dari keteguhan hati Muhammad Maliki (44 tahun) selaku Ketua Umum Kelompok Sentosa Sasak Tenun yang melihat permasalahan di tengah masyarakat, perihal ketidaksiapan para pengrajin tenun untuk membuat suatu kelompok. Kendala utama yang ditemukan oleh Muhammad Maliki pada saat itu adalah sulitnya mengubah pola pikir masyarakat untuk diajak kerjasama karena mereka lebih mementingkan kepentingan dan keuntungan pribadi. Namun, setelah mencoba bersabar dan berusaha berulang kali, akhirnya ada beberapa kelompok masyarakat yang bersedia menerima tawaran baiknya tersebut. Kemudian dibentuklah suatu kelompok tenun yaitu Sentosa Sasak Tenun, yang pada awalnya bernama Sleman Art Shop. Dengan demikian, terlihat bahwa adanya motivasi yang kuat dalam diri Muhammad Maliki untuk melestarikan dan 
mengembangkan kerajinan tenun gedogan sebagai ajaran turun-temurun dari para leluhur desa. Upaya tersebut, sekaligus dapat membantu meringankan biaya perekonomian sehari-hari masyarakat lokal, khususnya bagi para pengrajin perempuan untuk membantu meningkatkan kesejahteraan ekonomi rumah tangga, selain mengharapkan nafkah lebih dari sang suami.

Dalam hal produksi, Kelompok Sentosa Sasak Tenun selain memproduksi tenun dalam bentuk lembaran kain, namun juga memproduksi berbagai macam produk turunan seperti tas, dompet, sepatu, baju, celana, seprai, sarung bantal, syal, gorden, dan masih banyak produk turunan lainnya. Kelompok Sentosa Sasak Tenun merupakan salah satu kelompok tenun binaan Bank Indonesia sejak tahun 2016. Setelah berjalan 18 tahun lebih masa produksi, Kelompok Sentosa Sasak Tenun telah memiliki izin mendirikan bangunan berupa galeri tenun, dengan berdasar pada Surat Keputusan Kepala Badan Pengkajian dan Penerapan Teknologi Kabupaten Lombok Timur, yang dikeluarkan tanggal 01 Desember 2014, dengan Nomor: 5685/503/PPT.II.08/12/2014. Bersamaan dengan keputusan tersebut, Kelompok Sentosa Sasak Tenun juga telah memiliki Tanda Daftar Industri melalui Surat Keputusan Kepala BPPT Kabupaten Lombok Timur, yang dikeluarkan pada tanggal 01 Desember 2014, dengan Nomor: 5690/503/PPT.II.10/12/2014. Serta, telah mengantongi Tanda Daftar Perusahaan dalam bentuk Perusahaan Perseorangan, berdasarkan Surat Keputusan Kepala BPPT Kabupaten Lombok Timur, yang dikeluarkan pada tanggal 01 Desember 2014, dengan Nomor: 5689/503/PPT.II.05/MIKRO/12/2014.

Kelompok Sentosa Sasak Tenun menaungi lima kelompok tenun, yakni Kelompok Sentosa Sasak Tenun, Pesiraman, Sleman Adil, Sundawa Makmur, dan Aman Maksan. Jumlah pengrajin tenun beranggotakan 100 orang, dengan rincian sebanyak 97 orang didominasi oleh kaum perempuan dan tiga orang lainnya adalah pengrajin laki-laki. Dominansi terhadap jumlah anggota dari kaum perempuan dibandingkan dengan kaum laki-laki tersebut, secara tidak langsung memberikan kesimpulan singkat bahwa dengan bekerja sebagai pengrajin tenun, kaum perempuan juga dapat menunjukkan kemampuannya dalam hal membantu perekonomian keluarga.

Usaha kerajinan tenun gedogan dalam Kelompok Sentosa Sasak Tenun menurut UndangUndang Nomor 20 tahun 2008 tentang Usaha Mikro, Kecil, dan Menengah dapat dikategorikan sebagai kelompok usaha kecil, yaitu usaha ekonomi yang memiliki kekayaan bersih lebih dari Rp50.000.000,00 (lima puluh juta rupiah) sampai dengan paling banyak Rp500.000.000,00 (lima ratus juta rupiah) tidak termasuk tanah dan bangunan tempat usaha, atau memiliki hasil penjualan tahunan lebih dari Rp300.000.000,00 (tiga ratus juta rupiah) sampai dengan paling banyak Rp2.500.000.000,00 (dua miliar lima ratus juta rupiah). Namun, kategori ini juga bisa berbeda dengan kelompok tenun lainnya di Desa Wisata Pringgasela, karena setiap kelompok tenun memiliki kebijakan harga, metode promosi dan hasil penjualan yang berbeda-beda.

\section{B. Peranan Perempuan Kelompok Sentosa Sasak Tenun di Desa Wisata Pringgasela}

Kaum perempuan pada umumnya lebih banyak berperan dalam sektor domestik. Namun, tidak menutup kemungkinan apabila kaum perempuan tidak memiliki peran di sektor publik ataupun kemasyarakatan. Perkembangan zaman yang semakin modern membuat manusia saat ini dituntut untuk lebih produktif, kreatif dan inovatif. Tidak hanya kaum laki-laki saja, melainkan juga kaum perempuan. Analisis peranan perempuan dalam pengembangan usaha tenun gedogan pada Kelompok Sentosa Sasak Tenun di Desa Wisata Pringgasela dalam penelitian ini, menggunakan pendekatan peran sosial dan ekonomi perempuan dengan mengacu pada Model Tiga Peranan menurut Moser (1993), yang terdiri dari peran produktif, peran reproduktif, dan peran sosial. Untuk kelanjutan pembahasan mengenai peran sosial dan ekonomi perempuan, dapat dipahami dalam penjelasan sub-bab, sebagai berikut :

1. Peran Produktif Perempuan Kelompok Sentosa Sasak Tenun

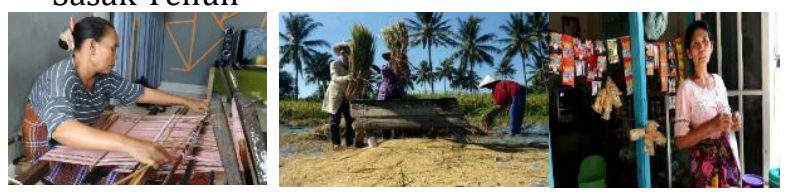

Gambar 1. Peran Produktif Perempuan Kelompok Sentosa Sasak Tenun

Sumber : Dokumentasi Penelitian Lapangan, 2019

Peran produktif adalah peran dalam meningkatkan pendapatan keluarga. Dalam Kelompok Sentosa Sasak Tenun, anggota kelompok dengan gender perempuan lebih mendominasi daripada laki-laki. Hal tersebut, mewakili pernyataan bahwa seorang perempuan juga memiliki hak untuk bekerja, mencari tambahan modal untuk membiayai kebutuhan perekonomian di dalam kehidupan rumah tangga. Dalam Kelompok Sentosa Sasak Tenun, tentunya pengrajin tidak hanya bekerja sebagai pengrajin tenun saja, ada pula yang berprofesi sebagai petani bagi pengrajin yang memiliki lahan pertanian, buruh tani bagi pengrajin yang tidak memiliki lahan pertanian, buruh ladang bagi pengrajin yang biasanya membersihkan lahan kebun milik orang lain, peternak bagi pengrajin yang memiliki hewan ternak (seperti sapi, kambing, ayam, bebek), dan ada pula yang berperan sebagai pedagang rumahan di teras rumah sembari menenun. Di dalam Kelompok Sentosa Sasak Tenun, belum ada yang 
berprofesi sebagai pegawai atau wiraswasta, karena biasanya seorang pegawai akan terikat oleh waktu kerja dan tidak akan sempat menenun untuk setiap harinya. Sebenarnya, menenun merupakan pekerjaan sampingan yang digeluti oleh para perempuan di Desa Wisata Pringgasela pada umumnya.

Dalam hal menenun, khususnya bagi pengrajin perempuan di Kelompok Sentosa Sasak Tenun, ratarata telah mengatur jadwal masing-masing. Strategi tersebut, bertujuan agar nantinya dapat membagi waktu dengan peran lain yang harus dikerjakan selain peran produktif sebagai penenun. Pengrajin biasanya mulai mengerjakan tenunannya pada pukul 08.30 WITA dan istirahat pada pukul 12.00 WITA. Kemudian, dilanjutkan kembali pada pukul 14.00 WITA sampai pada pukul 16.00 WITA. Ada pula beberapa pengrajin yang dalam usia nonproduktifnya mulai menenun pada pukul 06.00 WITA.

Menurut Ibu Idayanti (32 tahun) yang merupakan Ketua Kelompok Tenun Sleman Adil, yakni salah satu kelompok yang di bawahi oleh Kelompok Sentosa Sasak Tenun, menyatakan bahwa urusan kaum perempuan di sektor domestik seperti mengurus rumah tangga memang jauh lebih penting daripada urusan perempuan di sektor publik. Meskipun kaum perempuan di Desa Wisata Pringgasela mayoritas berperan sebagai pengrajin tenun, namun pengrajin tidak pernah membelakangi tanggung jawabnya terhadap urusan domestik (reproduktif). Pengrajin menganggap bahwa kegiatan menenun hanyalah pekerjaan sampingan yang fleksibel, kapanpun waktu ingin mengerjakan dan berapapun lembar kain perbulan yang dihasilkan. Pengrajin dapat mengatur diri sesuka hati. Terkait dengan peran perempuan sebagai pengrajin tenun, tentu ada beberapa motivasi yang membangun pengrajin untuk menekuni peranan tersebut, seperti membantu suami meringankan biaya untuk kebutuhan hidup sehari-hari, upaya melestarikan dan mengembangkan kain tradisional daerah, kebutuhan pakaian sehari-hari, prestise dalam hal regenerasi pengrajin tenun, dan beberapa motivasi lainnya.

Modal awal pengrajin dalam kegiatan menenun biasanya berasal dari dana pribadi dan terkadang mendapatkan pinjaman dana dari kelompok. Di setiap bulan biasanya pengrajin menghasilkan satu lembar kain dengan modal awal, yakni sekitar Rp150.000 untuk modal kain berbahan dasar benang dengan pewarnaan alami, dan Rp250.000 untuk modal kain berbahan dasar benang sintetis (kimia). Untuk harga kain tenun biasanya bervariasi, berkisar mulai dari Rp250.000 sampai dengan Rp450.000 untuk harga kain yang berbahan benang sintetis, dan berkisar mulai dari Rp450.000 sampai dengan jutaan rupiah untuk harga kain yang berbahan benang dengan pewarnaan alami. Sebenarnya, pemberian variasi harga terhadap kain tenun tergantung dari motif, jenis bahan benang, dan ukuran kain. Namun, biasanya harga tersebut bisa saja sewaktu-waktu akan berubah apabila pengrajin menjual hasil tenunannya dengan metode 'titip barang' di galeri tenun. Harga tersebut, berlaku hanya ketika wisatawan datang langsung membeli tenunan tersebut dari pihak pertama, yakni pengrajin. Penambahan harga kain yang dititipkan di galeri disebabkan karena per lembar kain yang terjual akan dipotong Rp50.000 untuk dimasukkan ke dalam kas kelompok. Setiap tanggal 10 November dan menjelang Hari Raya Idul Fitri atau Idul Adha, uang kas yang telah terakumulasi akan dibagikan secara merata ke semua anggota kelompok.

Dari hasil keuntungan penjualan kain tenun, biasanya para pengrajin menggunakannya sebagai modal untuk membeli kebutuhan rumah tangga, seperti kebutuhan dapur, belanja anak sekolah, dan sebagai tambahan modal untuk membeli lagi bahan tenun yang telah terpakai. Apabila dari hasil penjualan mendapatkan keuntungan yang besar, maka keuntungan tersebut biasanya akan langsung ditabung di bank atau digunakan untuk membeli emas sebagai barang aset rumah tangga. Meskipun, sebenarnya keuntungan dari penjualan kain tenun tersebut terbilang cukup untuk memenuhi kebutuhan rumah tangga. Dengan hasil yang cukup itupun para pengrajin sudah sangat bersyukur.

Para pengrajin berpendapat bahwa peran sebagai pengrajin tenun sama sekali tidak menghalangi peran mereka sebagai Ibu Rumah Tangga. Dengan memikirkan pembagian waktu secara cermat adalah kunci utama dari lancarnya tanggung jawab seorang perempuan dalam menyelesaikan tugasnya di sektor domestik maupun publik. Apabila kaum perempuan tidak cermat mengatur waktunya dalam mengerjakan peran produktif, peran reproduktif, dan peran sosialnya dalam waktu 24 jam, maka akan ada salah satu peran yang tidak bisa dijalankan dengan baik. Namun secara keseluruhan, semua anggota pengrajin perempuan di Kelompok Sentosa Sasak Tenun sudah menjalankan peranperannya dengan baik.

2. Peran Reproduktif Perempuan Kelompok Sentosa Sasak Tenun

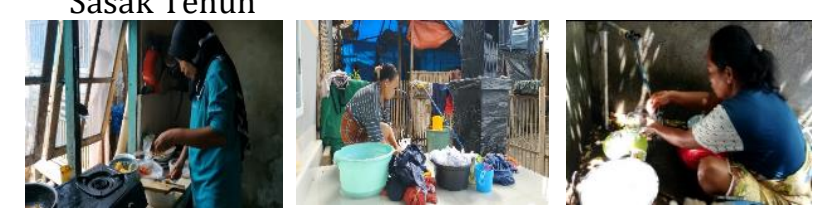

Gambar 2. Peran Reproduktif Perempuan Kelompok Sentosa Sasak Tenun

Sumber : Dokumentasi Penelitian Lapangan, 2019

Peran reproduktif perempuan, yaitu berupa perannya dalam keberlangsungan kehidupan rumah tangga, yang biasanya berkaitan dengan pekerjaan perempuan di sektor informal. Meskipun memiliki peran produktif, namun perempuan harus tetap menjalankan tanggung jawabnya dalam mengurusi 
urusan rumah tangga. Aktivitas untuk mengatur rumah tangga sudah menjadi kegiatan wajib bagi kaum perempuan, Anak perempuan pun sudah mulai diajarkan ketika masih kecil untuk dapat membantu ibunya dalam menata rumah tangga, dan diharapkan kelak akan mampu mengatur rumah tangganya sendiri. Melihat fakta di lapangan, terlihat bahwa pengrajin perempuan dalam Kelompok Sentosa Sasak Tenun memang sangat bertanggung jawab terhadap peran mereka sebagai Ibu Rumah Tangga. Peran dan tanggung jawab sebagai seorang istri dan ibu tidak pernah mereka kesampingkan. Menurut pengrajin, urusan menata rumah tanggalah yang harus lebih dulu diutamakan daripada urusan yang lain.

Para pengrajin biasanya melakukan peran reproduktifnya dimulai dari bangun Subuh, sekitar pukul 05.00 WITA untuk ibadah. Selanjutnya, membuatkan suami kopi dan mulai menyiapkan makanan untuk sarapan. Kemudian, dilanjutkan dengan tugas rumah tangga lainnya, seperti menyiram, menyapu, mencuci baju, menyetrika baju anak dan suami, dan urusan rumah tangga lainnya. Setelah semua urusan rumah tangga selesai, biasanya sekitar pukul 09.00 WITA, barulah saatnya pengrajin mulai mengerjakan tenunannya. Memiliki peran lebih sebagai seorang perempuan, terlebih lagi sebagai Ibu Rumah Tangga merupakan hal yang tidak mudah. Perlu pengaturan waktu yang cermat agar tidak terjadi hal-hal yang tidak diinginkan di dalam menjalankan peran sebagai seorang Ibu Rumah Tangga. Harus cermat dalam mengatur waktu, agar semua pekerjaan yang akan diperankan dapat dilaksanakan dengan baik.

Para pengrajin menyatakan bahwa peran reproduktif lebih penting dikerjakan terlebih dahulu, kemudian mengerjakan peran lainnya di luar menata rumah tangga dan mengurusi suami dan anak. Karena bagaimanapun, kodrat seorang istri adalah melayani suami terlebih dahulu, mengurusi anak, yang intinya adalah menata urusan rumah tangga. Para pengrajin akan tetap menjalankan perannya sebagai pengrajin tenun, namun setelah semua urusan rumah tangga sudah diselesaikan terlebih dahulu dengan baik. Terlebih lagi sebagai pengrajin tenun, menenun merupakan kegiatan sampingan yang bisa dikerjakan selama ada waktu luang. Pengrajin memiliki kebebasan dalam menentukan jam dan lama bekerja. Sehingga pengrajin tidak terikat oleh aturan yang mendesak.

Dorongan semangat yang dimiliki para pengrajin, yaitu jika seorang pengrajin tidak dapat mengatur waktu dalam mengerjakan tenunannya dengan baik, maka lembaran kain yang dihasilkan akan lama jadi, bahkan bisa memakan waktu hingga satu bulan lebih per lembar kain. Lain halnya dengan pengrajin yang sudah mampu mengatur waktu menenunnya dengan cermat, biasanya mereka bisa menghasilkan setengah meter kain per hari. Peran reproduktif perempuan merupakan peran di sektor domestik yang kerap dianggap paling penting dan fundamental dalam kehidupan seorang perempuan. Peran reproduktif secara umum tidak bisa dipisahkan oleh kehidupan perempuan. Peran itulah yang membangun pribadi perempuan agar mampu mandiri dalam menjalani kehidupan sebagai Ibu Rumah Tangga.

3. Peran Sosial Perempuan Kelompok Sentosa Sasak Tenun

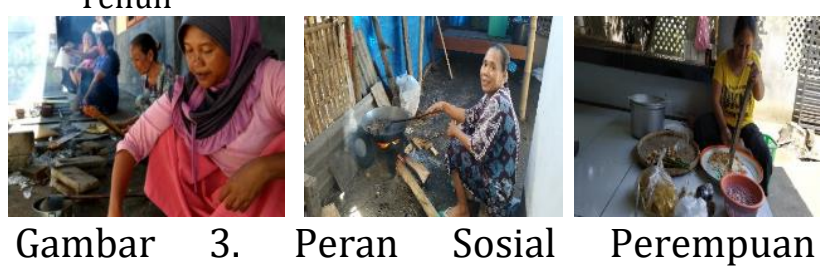

Kelompok Sentosa Sasak Tenun

Sumber : Dokumentasi Penelitian Lapangan, 2019

Seorang perempuan terlebih lagi sebagai Ibu Rumah Tangga, biasanya memiliki peran dalam masyarakat selain menjalankan peran produktif dan reproduktifnya. Sebagai bagian dari anggota Kelompok Sentosa Sasak Tenun, para pengrajin tenun tentunya memiliki peran sosial dalam kelompoknya. Di sisi lain, bagi perempuan yang sudah berkeluarga juga dipengaruhi oleh kehidupan sosial masyarakat tempat tinggalnya. Adapun peran sosial pengrajin tenun tersebut, antara lain; menjadi anggota grup Muslimat dari organisasi Nahdlatul Wathan yang acaranya berupa pengajian-pengajian, seperti yasinan dan hiziban. Acara pengajian tersebut, biasanya diadakan dalam satu minggu sekali. Ada pula yang satu bulan sekali, tergantung dari jenis acaranya. Peran pengrajin perempuan juga biasanya digunakan ketika ada kegiatan sosial di masyarakat. Terlebih lagi menyangkut acara adat dan tradisi desa, seperti begawe belek atau meroah, misalnya acara khitan (nyunatan), acara tujuh hari lahirnya bayi (molang malik), prosesi pemotongan rambut bayi (ngurisang), acara orang menikah (tau mulang), acara orang meninggal (tau mate), dan acara tradisi desa lainnya.

Selain adanya peran sosial dalam kegiatan keagamaan dan tradisi desa, para pengrajin juga ikut terlibat dalam kegiatan kesehatan dalam Kelompok Sentosa Sasak Tenun, yakni dalam kelompok POS UKK (Upaya Kesehatan Kerja). POS UKK merupakan pos kesehatan yang bekerja sama dengan PUSKESMAS Desa Pringgasela dalam hal melayani kesehatan semua anggota Kelompok Sentosa Sasak Tenun. Biasanya dilakukan satu kali sebulan di Sekretariat Kelompok Sentosa Sasak Tenun yang berlokasi di Jalan Rinjani, RW Sentosa, Desa Pringgasela, Kecamatan Pringgasela, Kabupaten Lombok Timur. Selain hidup berumah tangga, manusia juga harus mampu hidup bermasyarakat, yaitu dengan meningkatkan jiwa kegotong-royongan. Manusia dalam kodratnya sebagai makhluk sosial 
yang hidup bermasyarakat, tentunya akan membutuhkan peran dari makhluk sosial lainnya.

Dari penjelasan ketiga model peranan perempuan di Kelompok Sentosa Sasak Tenun tersebut, dapat dipahami lebih mendalam melalui tampilan pada tabel, sebagai berikut:

Tabel 1. Model Tiga Peranan Perempuan Kelompok Sentosa Sasak Tenun

\begin{tabular}{|c|c|c|}
\hline $\begin{array}{c}\text { Peran } \\
\text { Produktif }\end{array}$ & $\begin{array}{c}\text { Peran } \\
\text { Reproduktif }\end{array}$ & $\begin{array}{l}\text { Peran } \\
\text { Sosial }\end{array}$ \\
\hline $\begin{array}{l}\text { 1. Penenun } \\
\text { 2. Petani } \\
\text { 3. Buruh Tani } \\
\text { 4. Buruh } \\
\text { Ladang } \\
\text { 5. Peternak } \\
\text { 6. Pedagang } \\
\text { Rumahan }\end{array}$ & $\begin{array}{l}\text { Kegiatan } \\
\text { menata rumah } \\
\text { tangga, } \\
\text { mengurusi } \\
\text { suami dan } \\
\text { anak, antara } \\
\text { lain; } \\
\text { 1. Memasak } \\
\text { 2. Mencuci } \\
\text { perabotan } \\
\text { rumah } \\
\text { tangga dan } \\
\text { pakaian } \\
\text { 3. Menyetrika } \\
\text { pakaian } \\
\text { 4. Menyapu } \\
\text { 5. Menyiram }\end{array}$ & $\begin{array}{l}\text { Kegiatan } \\
\text { Muslimat } \\
\text { Nahdlatul } \\
\text { Wathan, antara } \\
\text { lain; } \\
\text { 1. Yasinan } \\
\text { 2. Hidziban } \\
\text { Kegiatan adat } \\
\text { dan tradisi } \\
\text { masyarakat } \\
\text { begawe belek, } \\
\text { antara lain; } \\
\text { 1. Nyunatan } \\
\text { 2. Molang malik } \\
\text { 3. Ngurisang } \\
\text { 4. Tau mate } \\
\text { 5. Tau mulang } \\
\text { 6. Dan acara adat } \\
\text { lainnya } \\
\text { Kegiatan } \\
\text { kesehatan; Pos } \\
\text { UKK (Upaya } \\
\text { Kesehatan Kerja) }\end{array}$ \\
\hline
\end{tabular}

Sumber : Hasil Penelitian Lapangan, 2019

Sehubungan dengan Tabel 1. tersebut, terkait dengan peranan perempuan di Kelompok Sentosa Sasak Tenun dalam pariwisata dapat dilihat dari kecintaan para pengrajin terhadap peninggalan seni dan tradisi yang telah diwariskan oleh para leluhur. Hal tersebut membuat kaum perempuan di Desa Wisata Pringgasela memiliki motivasi yang kuat terkait ketekunan mereka untuk melestarikan dan mengembangkan kerajinan tenun gedogan tersebut sampai dengan saat ini. Kemajuan ilmu pengetahuan, teknologi dan berkembang pesatnya pengaruh globalisasi dalam kehidupan masyarakat secara umum tidak menutup niat mulia para pengrajin tenun untuk tetap mempertahankan aset berharga yang dimiliki Desa Wisata Pringgasela tersebut.

Tenun merupakan salah satu produk atau daya tarik wisata yang dapat menarik perhatian wisatawan berkunjung. Terlebih bagi wisatawan Mancanegara, sebagaimana di negara asal mereka tidak memiliki potensi wisata tersebut. Wisatawan juga nantinya akan dapat terlibat secara langsung dalam proses menenun. Hal tersebutlah yang menjadi pengalaman berharga bagi wisatawan. Secara tidak langsung, citra Desa Wisata Pringgasela semakin dikenal oleh khalayak ramai, baik dalam lingkup lokal, nasional, maupun internasional. Peranan perempuan dalam pengembangan terhadap kerajinan tenun gedogan ini pula nantinya akan dapat dijadikan sebagai cikal bakal pengembangan pariwisata budaya di Desa Wisata Pringgasela. Ide tersebut, didukung oleh kenyataan bahwa Desa Wisata Pringgasela merupakan salah satu desa wisata berkembang di Kabupaten Lombok Timur, yang masih dan tetap mempertahankan, melestarikan dan mengembangkan produksi kerajinan turun-temurun lokal daerah dalam bentuk kain tenun dan masih menggunakan alat tradisional yang disebut gedogan sampai dengan saat ini.

\section{KESIMPULAN}

\section{A. Simpulan}

Peranan perempuan Kelompok Sentosa Sasak Tenun di Desa Pringgasela memiliki tiga peranan, sebagai berikut.

1. Peran produktif, yaitu peran perempuan sebagai pengrajin tenun gedogan, petani, buruh tani, buruh ladang, peternak, dan pedagang rumahan.

2. Peran reproduktif, yaitu peran perempuan dalam menata kehidupan rumah tangga, seperti menyiram, menyapu, mencuci baju, menyetrika baju anak dan suami, dan urusan rumah tangga lainnya.

3. Peran sosial, yaitu peran perempuan sebagai anggota grup Muslimat Nahdlatul Wathan, kegiatan adat dalam acara begawe belek, dan kelompok kesehatan yakni POS UKK (Upaya Kesehatan Kerja).

Dari ketiga model peranan perempuan tersebut, yang menjadi peran utama (fundamental) pengrajin perempuan di Kelompok Sentosa Sasak Tenun adalah peran reproduktif. Sebagaimana di dalam peran reproduktif, eksistensi untuk mempertahankan keharmonisan dan kesejahteraan rumah tangga merupakan tanggung jawab kaum perempuan. Perempuan tetap memegang peranan penting dalam urusan rumah tangganya. Sebagai seorang istri dan ibu, kodrat seorang perempuan adalah menata urusan rumah tangga. Setelah peran reproduktif perempuan sudah terlaksana dengan baik, maka perempuan akan beralih ke peran lainnya, yaitu peran produktif maupun peran sosial (kemasyarakatan). 


\section{DAFTAR PUSTAKA}

Ahdiah, I. 2013. Peran-peran Perempuan dalam Masyarakat. JURNAL ACADEMICA Fisip Untad, 05(02), 1085-1092. Retrieved from http://jurnal.untad.ac.id/jurnal/index.php/aca demica/article/view/2247

Anom, I Putu dan Mahagangga, I Gusti Agung Oka. Handbook Ilmu Pariwisata Karakter dan Prospek. Jakarta: Prenada Media

Arikunto, S.. (2006). Prosedur penelitian suatu pendekatan praktik. Jakarta: Rineka

Bungin, B. 2007. Penelitian Kualitatif. Jakarta: Kencana.

Dewi, P. A. P. S., \& Mahagangga, I. G. A. O. 2016. Triple-Roles Perempuan Pengelola Art Shop di Pantai Sindhu Kelurahan Sanur Denpasar Selatan. Jurnal Destinasi Pariwisata, 4(2), 14$19 . \quad$ Retrieved from https://ojs.unud.ac.id/index.php/destinasipar /article/view/25320

Hartanto, R. V. P., \& Firdausy, A. G. 2010. Evaluasi Terhadap Pelaksanaan Instruksi Presiden Nomor 9 Tahun 2000 Tentang Kebijakan Pengarusutamaan Gender Oleh Pemerintah Kota Surakarta. Yustisia, 81, 45-54. Retrieved from https://eprints.uns.ac.id/15646/

Intani, R. 2010. Tenun Gedogan Dermayon. Patanjala: Jurnal Penelitian Sejarah Dan Budaya, 2(1), 35-47. https://doi.org/10.30959/patanjala.v2i1.204

Kartia, W. 2017. Peran Perempuan Penenun Kain Mandar (Panette) Terhadap Kesejahteraan Keluarga di Desa Karama Kecamatan Tinambung Kabupaten Polewali Mandar (Universitas Islam Negeri Alauddin Makassar). https://doi.org/10.1017/CB09781107415324 .004

Manembu, A. E. 2017. Peranan Perempuan Dalam Pembangunan Masyarakat Desa (Suatu Studi di Desa Maumbi Kecamatan Kalawat Kabupaten Minahasa Utara). Jurnal Politico, 6(1), 1-28. Retrieved from https://ejournal.unsrat.ac.id/index.php/politic o/article/view/16329

Moleong, L. 2012. Metodologi Penelitian Kualitatif. GP Press Group. Jakarta

Pratiwi, L. P. A. K., \& Nugroho, S. 2013. Peranan Perempuan Penjual Postcard di Kawasan Daya Tarik Wisata Khusus Tanah Lot Dalam Sektor Domestik Dan Publik. Jurnal Destinasi Pariwisata, 1(1), 63-72. Retrieved from https://ojs.unud.ac.id/index.php/destinasipar /article/view/22932

Suci, Y. R. 2017. Perkembangan UMKM (Usaha Mikro Kecil Dan Menengah) di Indonesia. Jurnal Ilmiah Cano Ekonomos, 6(1), 51-58. Retrieved from https://www.neliti.com/publications/58432/ perkembangan-umkm-usaha-mikro-kecil-dan- menengah-di-indonesia

Suryawan Ida Bagus dan Mahagangga, I Gusti Agung Oka. 2017. Penelitian Lapangan 1. Denpasar: Cakra Press dan Fakultas Pariwisata. 